УДК: $338.24+331.5$

\author{
Круалов Віталій,
} канд. наук з держ. упр.

ORCID iD 0000-0002-7228-8635

E-mail: virt197@gmail.com

\title{
ДЕРЖАВНА ПОЛІТИКА ТРАНСФОРМАЦЇ̈ РИНКУ ПРАЦІ: ВИКЛИКИ ЦИФРОВОЇ ЕПОХИ
}

\section{https://doi.org/10.32689/2618-0065-2021-1(7)-140-161}

\begin{abstract}
Анотація. Процеси технологічних змін, які позначилися на забезпеченні життєдіяльності держави, виробництва, відобразилися у переважній більшості людської діяльності - $\epsilon$ наслідком стрімкого розвитку цифрової економіки. Породжені інноваційними технологіями нові напрями діяльності підприємств, установ та організацій вимагають наявності у персоналу відповідних фахових навичок, пов'язаних зі знаннями цифрової економіки. Мета дослідження полягає в аналізі сучасного стану державної політики трансформації ринку праці та формування підходів щодо впровадження змін 3 урахуванням викликів цифрової епохи. Як показує процес розвитку ринку праці, цифровізація та технологічний прогрес значно вплинули на економічну діяльність, виявивши вимоги щодо адаптивних навичок фахівців. Це, в свою чергу, в найближчому майбутньому призведе до значного скорочення та ліквідації робочих місць. Цифрова трансформація є складними змінами за рахунок посиленого впливу технологій, спрямованими на відносини у суспільній та економічній сферах. Концепція Industry 4.0 передбачає виникнення та подальший розвиток сучасних інноваційних напрямів діяльності. Нагальною постає потреба отримання та адаптування працездатного населення до мінливих вимог ринку праці. Впровадження нових напрямів потребуватиме значної кількості найманих працівників, в той же час - зникнення неактуальних напрямів призведе до значного рівня безробіття. Визначено, що перед державною політикою, пов'язаною 3 трансформації ринку праці, постають питання, спрямовані на: врегулювання балансу між виконанням роботи людьми та автоматизованими системами; контроль за безпечним використанням провідних технологій; формування необхідного середовища для підприємницької конкуренції; збільшення фінансування НДДКР; розбудову цифрової інфраструктури; впровадження стимулюючого характеру в оплаті праці в наукоємних та інноваційних сферах діяльності; законодавче упорядкування питань, пов'язаних 3 виконанням віддаленої роботи; посилення інституційних меж захисту інтелектуальної власності; державну підтримку суб'єктів інноваційної діяльності; залучення значних інвестицій у розвиток наукової та освітньої сфери; перепідготовку фахівців у різних сферах діяльності та працевлаштування.
\end{abstract}

Ключові слова: державна політика, ринок праці, цифрова трансформація, інформаційно-комунікативні технології 


\section{Науковий вісник : Державне управління №1 (7) 2021}

Постановка проблеми. Зміни, що торкнулися соціальноекономічної сфери держави в сьогоднішніх умовах, набувають значних масштабів, а наслідки змін мають незворотній характер. Складні трансформаційні процеси впливають на темпи технологічного розвитку, можливості використання людського капіталу, забезпечення необхідного рівня зайнятості, потреби ринку праці, особливості формування державної політики щодо напрямів, які безпосередньо можуть забезпечити інноваційний розвиток (цифровий бізнес, інтернет-економіка, наука, освіта, автоматизоване виробництво). Межі між традиційним та електронним бізнесом 3 кожним роком все більше стираються, посилюючи конкурентну боротьбу, створюючи нові ринкові ніші, інноваційні виробництва та формуючи потреби в фахівцях, які спроможні вирішувати завдання у високотехнологічних сферах діяльності. Постійно зростає кількість спеціальностей, які суттєво пов'язані $з$ технологіями. Виникає необхідність впровадження нових підходів до державної політики у сфері зайнятості, що передбачає визначення нагальних потреб у розвитку інноваційних напрямів діяльності та адаптації наявних трудових ресурсів до актуальних тенденцій розвитку цифрових технологій. Причому зменшення цифрового відставання, впровадження наукоємних технологій призводить до посилення конкурентних переваг та розширює можливості виходу на зовнішні ринки.

Аналіз останніх досліджень і публікацій. Питання, пов'язані з формуванням державної політики ринку праці, стають дедалі актуальними у сучасних наукових дослідженнях, особливо в поєднанні з проблематикою впливу цифрової економіки.

В. Костриця та Т. Бурлай, аналізуючи державну політику у сфері зайнятості у період Четвертої промислової революції, акцентують увагу на необхідності впровадження політики розвитку ринку праці (перекваліфікація робочої сили), створення нових робочих місць, інвестування у розвиток людського капіталу [1]. У дослідженні С. Туль робиться висновок, що посилення впливу цифровізації на ринок праці породжує: зростання кількості працівників з віддаленою формою зайнятості, розширення цифрових складників процесу пошуку роботи 


\section{Науковий вісник : Державне управління №1 (7) 2021}

(online-платформи для пошуку роботи), збільшення кількості нетипових форм зайнятості (аутсорсинг, фріланс) [2].

Низка науковців роблять висновок, що вдосконалена цифровізація та автоматизація роботи, відома як «четверта промислова революція», матиме значний вплив на особистий досвід майбутньої кар'єри, змінивши основу роботи, працевлаштування та ведення бізнесу в майбутньому [3]. Також передбачається, що ці зміни ліквідують тисячі робочих місць [4], а завдяки значному розвитку штучного інтелекту до 2025 p. зникне третина робочих місць [5].

С. Король та Є. Польовик зазначають, що процеси цифровізації створюють кваліфікаційні розриви, ризики безробіття, інші проблеми. Подолання негативних явищ вимагає державної підтримки, одним із напрямів якої $є$ перепідготовка фахівців з урахуванням існуючих тенденцій на ринку праці [6]. На думку Дж. Ріфкіна [7], об’єднання нових комунікаційних технологій, джерел енергії та засобів пересування продукує фундаментальні зміни в способах роботи людей. На думку О. Хандій та Л. Шамілева, виникає необхідність визначення балансу між попитом та пропозицією робочої сили, що, в свою чергу, передбачає процеси підготовки закладами освіти фахівців, які спроможні конкурувати на сучасному ринку праці, враховуючи високий рівень володіння цифровими навичками [8].

Не применшуючи сучасні наукові розвідки вітчизняних та зарубіжних дослідників, варто зауважити, що окремим питанням державної політики трансформації ринку праці в умовах впливу цифрової епохи приділено недостатньо уваги, та потребують окремого поглибленого розгляду підходи до формування державної політики у зазначеній сфері.

Методи дослідження. Для досягнення поставленої мети дослідження використано монографічний метод (аналіз розвитку сфери державного регулювання ринку праці в Україні та світі), емпіричний метод (комплексна оцінка сучасного стану ринку праці та оцінка готовності до майбутнього виробництва), порівняльного аналізу (визначено особливості та проблеми стану ринку праці в процесі цифрової трансформації, виявлено зміни 


\section{Науковий вісник : Державне управління №1 (7) 2021}

індикаторів стану ринку праці), абстрактно-логічний метод (теоретичні узагальнення та формулювання висновків).

Метою статті $\epsilon$ аналіз сучасного стану державної політики трансформації ринку праці та формування підходів щодо впровадження змін з урахуванням викликів цифрової епохи.

Виклад основного матеріалу. Динамізм на ринку праці виявляє себе у постійній зміні актуальних професій, потреби в яких зростають або, навпаки, зменшуються до цілковитого зникнення. Проблематика появи спеціальностей, пов'язаних 3 впливом цифровізації на економічні процеси, ставить відповідні вимоги до компетентності фахівців, які повинні мати високу адаптивність та мати наміри навчатися протягом життя. Постіндустріальна модель суспільства виявила ключову роль у створенні нових знань, важливість інтелектуального чинника у виробництві, необхідність забезпечення високоякісними послугами, цінність партнерських відносин.

Цифрова економіка - це тактика господарювання, де оцифровані знання й інформація - ключовий виробничий фактор, сучасні інформаційні мережі - носій інформації, а інформаційнокомунікаційні технології (IКТ) - рушійна сила продуктивності й оптимізації структури економіки [9].

Вітчизняне розуміння цифрової трансформації (Digital transformation), передбачає, що останнє $є$ організаційними чи суспільними змінами на основі впровадження цифрових технологій в усі аспекти взаємодії з людиною. Трансформаційні зміни виявляються в разі виникнення інноваційних методів роботи в процесі використання технологій, що заміщує просте розширення або підтримку традиційних підходів [10]. Основу цифрової трансформації становить технологічний аспект, набори даних та бізнес-моделі як рушійні сили, що лежать в основі зазначеної трансформації [11], і спираються на аналіз «векторів» цифрової трансформації у багатьох сферах політики [12]. Структура включає взаємопов'язані виміри політики: доступ; використання; інноваційність; робочі місця; соціальне процвітання; довіру; відкритість ринку. Використання переваг та вирішення проблем цифрової трансформації вимагає координації 
в усіх сферах державної політики, що передбачає розгляд питань (наприклад, навичок та цифрового уряду), які дотичні до інших аспектів структурної політики [11].

Розглядаючи та аналізуючи зміни, які спричинені цифровими інноваціями, та наслідки вказаних змін, ключовим завданням постає розроблення підходів, встановлення завдань та способів вирішення проблематики на ринку праці. Сучасні дослідники під дефініцією «політика» розуміють заходи, засоби та узгоджені дії, які дозволяють досягти встановлених цілей у певних галузях чи сферах [13]. У контексті зазначеної статті державна політика змін на ринку праці розглядається як сформована на основі принципів, цільових орієнтирів та наявності необхідних засобів діяльність суб'єктів державної влади, спрямована на розв'язання ключових проблем чи протиріч, а саме - наслідків цифрової трансформації.

На рис. 1 представлено, відповідно до концепції Industry 4.0, напрями та сутність нових технологій, які продовжують розвиватися, вимагаючи підготовки та залучення висококваліфікованих кадрів у вказані сфери діяльності.

Виходячи 3 поданих на рис. 1 напрямів, які передбачаються концепцією Індустрія 4.0, можна зазначити, що більшість 3 них досить вузько представлені в промисловій та технологічній сфері в Україні, а окремі напрями допоки не мають свого розвитку. Крім того, враховуючи технологічну відсталість України в реалізації інноваційних напрямів розвитку та недостатнє фінансування, не формуються i не впроваджуються нові актуальні напрями підготовки фахівців закладами освіти та відсутня можливість проведення повноцінних науково-дослідних і дослідно-конструкторських робіт.

Насамперед, ключові технології Індустрії 4.0 можуть слугувати в якості напрямів, які мають враховуватися при формуванні державної політики змін на ринку праці.

В результаті явищ, пов'язаних 3 Четвертою промисловою революцією, i рецесії, пов'язаної з COVID-19, повсякденна цифровізація різко прискорилася 3 масштабним переходом до віддаленої роботи та електронної комерції, що призвело до 


\section{Науковий вісник : Державне управління №1 (7) 2021}

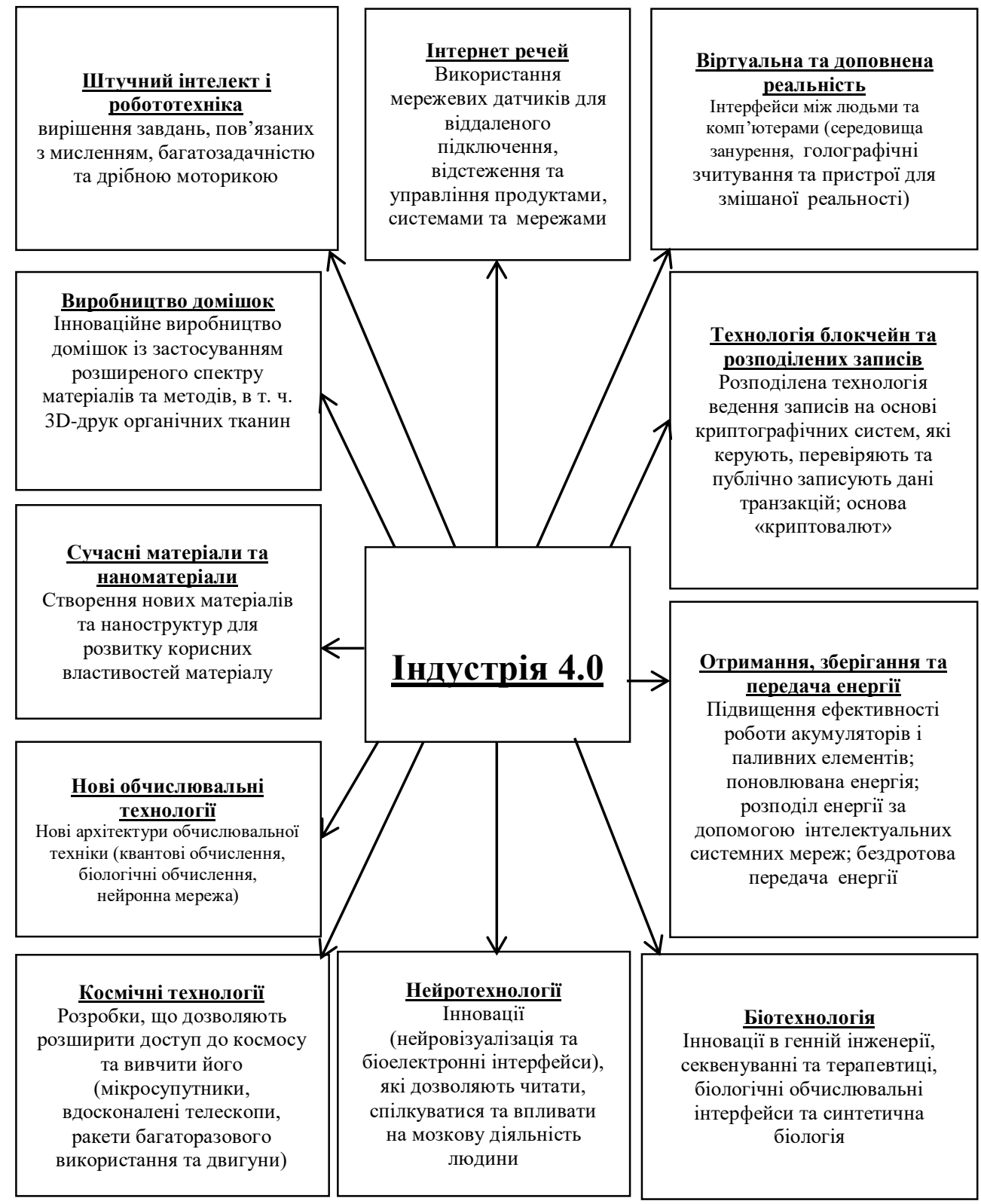

\section{Рисунок 1 - Ключові новітні технології}

Джерело: побудовано на основі [14]. 


\section{Науковий вісник : Державне управління №1 (7) 2021}

різкого збільшення числа нових майданчиків для віддаленої роботи [15].

У період з 1999 по 2019 рік, незважаючи на те, що чисельність молоді (у віці 15-24 років) у світі зросла 31 млрд до 1,3 млрд, загальна кількість зайнятих роботою молодих людей зменшилася 3568 млн до 497 млн [16]. Валовий коефіцієнт охоплення середньою освітою у всьому світі зріс з 59 \% у 1999 р. до 76 \% у 2018 р.; відповідний коефіцієнт вищої освіти за той самий період зріс 318 до 38 \% [17]. Прогнозується, що глобальний рівень безробіття серед молоді зросте на 0,1 в. п. в 2020 р. порівняно 32019 р. (до 13,1\%) та до 13,2 \% в 2021 р. Загалом молоді люди (у віці 18-35 років) частіше, ніж люди старшого віку користуються Інтернетом або володіють смартфоном, що відображає «цифровий розрив» між поколіннями [16].

В контексті формування державної політики ринку праці, слід врахувати завдання Цілей сталого розвитку (ЦУР) 4.4, де визначено, що до 2030 р. необхідно значно збільшити кількість молоді та дорослих, які мають відповідні навички, включаючи технічні та професійні навички, для працевлаштування та підприємництва. Навички інформаційно-комунікаційних технологій мають вирішальне значення для того, щоб люди могли отримати доступ до нових можливостей та адаптуватися до мінливих вимог ринку праці в епоху «Індустрії 4.0» [16].

У III-IV кварталі 2020 р. під час «коронокризи» зростання рівня безробіття в Україні було дуже стрімким. Наявні високочастотні індикатори свідчать про порівняно швидке відновлення ринку праці, що дає підстави очікувати зростання рівня зайнятості (рис. 2).

Утім у сезонно скоригованому вимірі зниження рівня безробіття буде незначним. Це зумовлено очікуваним поверненням до робочої сили частини тих, хто втратив роботу в попередні періоди, проте 3 різних причин не шукав роботу (відповідно, такі особи віднесені до економічно неактивного населення). Саме цей чинник пояснює, чому рівень безробіття в II кварталі був нижчим за очікування [18]. Виходячи 3 даних на 


\section{Науковий вісник : Державне управління №1 (7) 2021}

рис. 2, слід відмітити і таку особливість - пропозиції нових вакансій, розміщених на сайті work.ua, та актуальних вакансій Державної служби занятості України (ДСЗУ) значно менші, ніж кількість офіційно зареєстрованих безробітних, що дає можливості одним із напрямів державної політики трансформації ринку праці визначити спрямування державних коштів, враховуючи можливості ДСЗУ, на забезпечення перепідготовки визначеної кількості фахівців у сферах, які вимагають поглибленого використання інформаційно-комунікативних технологій.

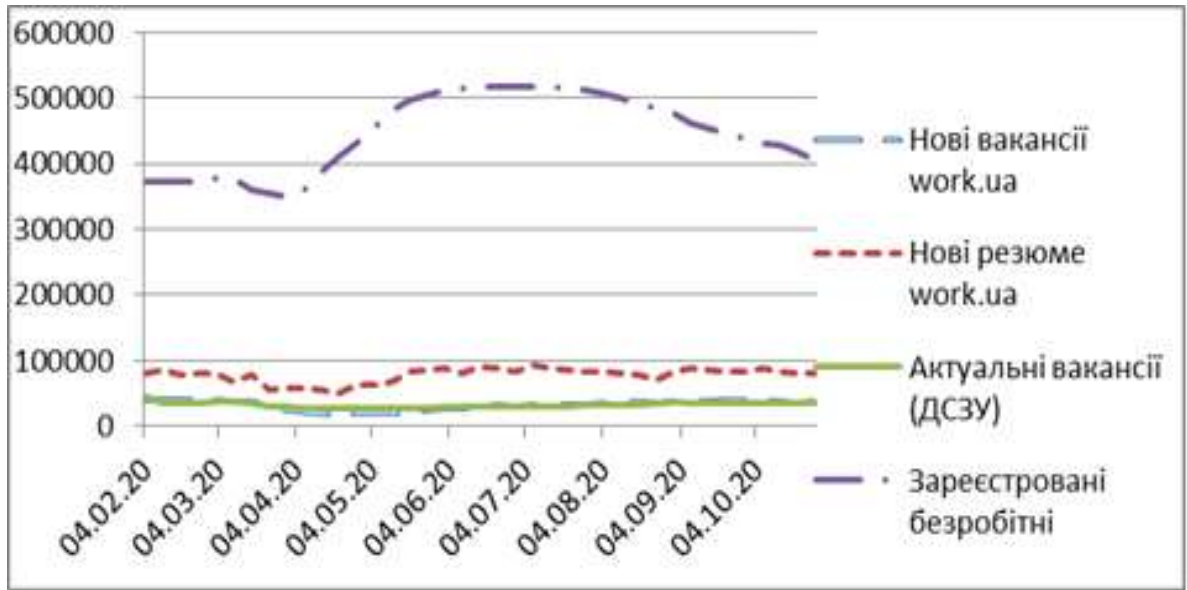

Рисунок 2 - Високочастотні індикатори стану ринку праці

Джерело: побудовано на основі [18].

Четверта промислова революція, демографічні зміни, промислові перетворення та зміни потреб споживачів створюють попит на мільйони нових робочих місць 3 величезними можливостями для реалізації потенціалу та сподівань людей. Однак, щоб перетворити ці можливості в реальність, у всьому світі терміново необхідні нові джерела даних та інноваційні підходи до розуміння виникаючих робочих місць і навичок, а також для розширення можливостей ефективних i скоординованих масштабних дій [19]. 


\section{Науковий вісник : Державне управління №1 (7) 2021}

До основних навичок i груп навичок, які, на думку роботодавців, будуть рости до 2025 р., відносяться критичне мислення й аналіз, вирішення проблем, а також навички саморозвитку та вдосконалення (активне навчання, стійкість, стресостійкість, гнучкість) [15].

Нові професії майбутнього, проаналізовані в дослідженні Всесвітнього економічного форуму, становитимуть 6,1 млн можливостей працевлаштуватися в 2020-2022 рр. Згідно з цими припущеннями, якщо поточні тенденції зростання збережуться, ці нові професії нададуть до 2,4 млн можливостей до 2022 р. У сукупності в найближчі три роки $37 \%$ передбачуваних можливостей працевлаштування в нових професіях буде в сфері, пов'язаній з доглядом; 17\% - у торгівлі, маркетингу та реалізації інформаційного товару; 16\% - у сфері обробки даних і штучного інтелекту; 12\% - у сфері інженерії та хмарних обчислень; 8\% - у сфері, що пов'язана з людьми та культурою [19].

У той час як проривні технологічні навички, такі як наука про дані та навички штучного інтелекту, безумовно, будуть мати вирішальне значення для майбутньої роботи, так само будуть важливими догляд, лідерство та здатність забезпечувати навчання та розвиток. Нарешті, зростання й абсолютний масштаб ряду цих професій будуть чітко визначатися вибором і інвестиціями, які забезпечує держава. Нові інвестиції в «зелену» економіку (акцент на поновлювані джерела енергіï), можуть привести до розширення перспектив зайнятості в цьому секторі. Нове регулювання даних вже підвищило попит на працівників, які можуть виконати вимоги до зберігання, збору та використання великих даних. Важливо відзначити, що незалежно від кількості новостворених робочих місць або відкритих вакансій, тип робочих місць, які відкриваються, буде змінюватися відповідно до потреб мінливих технологічних, демографічних і економічних реалій [20].

Оцінка готовності до майбутнього виробництва, що розроблена 3 ініціативи Всесвітнього економічного форуму, складається 3 двох основних компонентів: структури виробництва або поточного базового рівня виробництва країни, i 
рушіїв виробництва, або ключових факторів, що дозволяють країні скористатися Четвертою промисловою революцією для трансформації виробничих систем [14]. Україна, відповідно до двох показників (рушії виробництва - 4,5; структура виробництва - 5,2) знаходиться в секторі, який характеризується обмеженою виробничою базою та появою небезпеки в майбутньому (рис. 3).

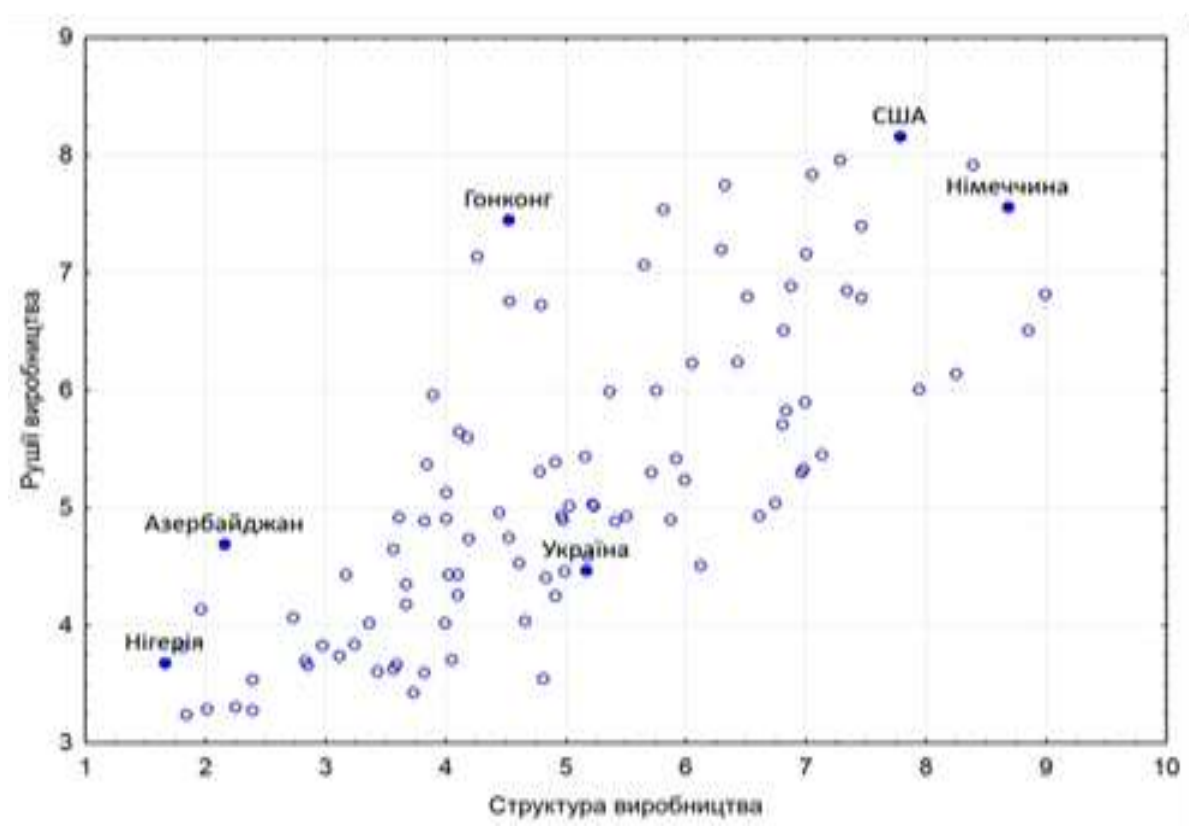

Рисунок 3 - Результати оцінки готовності до майбутнього виробництва

Джерело: побудовано на основі [14]

Виходячи із інформації, представленої на рис. 3, напрямами, які можуть позитивно вплинути на реалізацію державної політики трансформації ринку праці, можуть стати: оновлення технологічної інфраструктури, впровадження ресурсоощадних інновацій; розвиток людського капіталу (освіта, охорона здоров'я, залучення іноземних фахівців); посилення інвестиційної привабливості за рахунок наявності технологічних 


\section{Науковий вісник : Державне управління №1 (7) 2021}

платформ, виробничих систем, інноваційних кластерів; удосконалення інституційного середовища (ефективне державне регулювання, захист інтелектуальної власності, верховенство права, наявність стратегічних документів щодо розвитку ключових галузей економіки); сприяння виходу національної продукції на зовнішні ринки.

Окремі розрахунки свідчать, що в країнах Великої двадцятки повне задоволення попиту на ринку праці на нові професії та навички для задоволення потреб нової технологічної ери може збільшити зростання ВВП на 11,5 трлн дол США протягом наступного десятиліття [21]. Згідно 3 оцінкою Всесвітнього економічного форуму у 2018 р., в глобальному масштабі трансформація ринку праці, викликана Четвертою промисловою революцією, може привести до створення 133 млн нових робочих місць і одночасного переміщення 75 млн робочих місць протягом 2018-2022 pp. [22].

Зростаючий попит на актуальні професії ще більше підвищив цінність ряду відмінних наборів навичок, які лежать в основі професійних кластерів та їх перспективи зростання та процвітання в новій економіці. Зазначені навички згруповані в кластери: бізнес-навички, спеціалізовані галузеві навички, загальні та м'які навички, базові технічні навички та технічні навички підривних інновацій. Бізнес-навички - це набір навичок, необхідних для роботи або відкриття підприємства (наприклад, маркетинг, управління проектами, бюджетування та розвиток бізнесу). Спеціалізовані галузеві навички відносяться до сфери розглянутих професій, пов'язаних 3 хмарними обчисленнями, торгівлею та ін. Загальні навички (також відомі як кросфункціональні навички) зазвичай некогнітівні здатності, необхідні в усіх професіях (наприклад, лідерство, спілкування, переговори, творчість і вирішення проблем). LinkedIn зіставив більшість загальних навичок 3 кластером м'яких навичок, який включає в себе поведінкові навички, такі як лідерство. Базові технічні навички охоплюють базову комп'ютерну грамотність, таку як здатність використовувати галузеві технологічні додатки (наприклад, веб-дизайн, онлайн-маркетинг, соціальні мережі, 


\section{Науковий вісник : Державне управління №1 (7) 2021}

телекомунікації, програмне забезпечення для інженерного дизайну, медичне програмне забезпечення). Навички підривних інновацій дозволяють людям використовувати та розробляти технології, що мають значний вплив на бізнес-моделі та ринок праці в найближчі роки (наприклад, наука про дані, автоматизація, робототехніка, хмарні обчислення та кібербезпека) [19].

До 2025 p. можливості машин i алгоритмів будуть використовуватися більш широко, ніж в попередні роки, а час роботи машин буде відповідати часу, витраченому на роботу людьми. Збільшення кількості робочих місць порушить перспективи працевлаштування працівників у широкому спектрі галузей і регіонів. Нові дані дослідження Future of Jobs Survey показують, що в середньому $15 \%$ співробітників компанії схильні до ризику перебоїв в роботі на горизонті до 2025 р., а в середньому очікується повне звільнення $6 \%$ робітників. Таким чином, підприємства прагнуть надати можливості перепідготовки та підвищення кваліфікації для більшості своїх співробітників (73\%), усвідомлюючи той факт, що до 2025 р. 44\% навичок, які будуть потрібні співробітникам для ефективного виконання своїх ролей, зміняться [15].

За даними Міжнародної організації праці (ILO), в першій половині 2020 р. реальні показники безробіття підскочили до середнього рівня (6,6\% у другому кварталі 2020 р.). ОЕСР прогнозує, що до кінця 2020 р. показники можуть досягти піку на рівні 12,6\% і можуть скласти 8,9\% до кінця 2021 р. [23]. Міжнародна організація праці прогнозує, що до другого кварталу 2020 р. буде звільнено 195 млн працівників, а робочі місця будуть змінюватися більш швидкими темпами [24].

Згідно з новим аналізом, проведеним МВФ, 97,3 млн чоловік, або приблизно $15 \%$ робочої сили в 35 країнах, включених в аналіз, класифікуються як такі, що підпадають під високий ризик звільнення [23]. Розрахункова частка працівників, схильних до ризику безробіття, відповідно до секторів, представлена на рис. 4, де ми бачимо, що найбільші ризики безробіття виявлено у сфері послуг 3 харчування та проживання (47\% зайнятості у секторі). 
Іншу групу складають сектори 3 більш помірними ризиками безробіття (транспорт, освіта, торгівля, будівництво, охорона здоров'я та ін.).

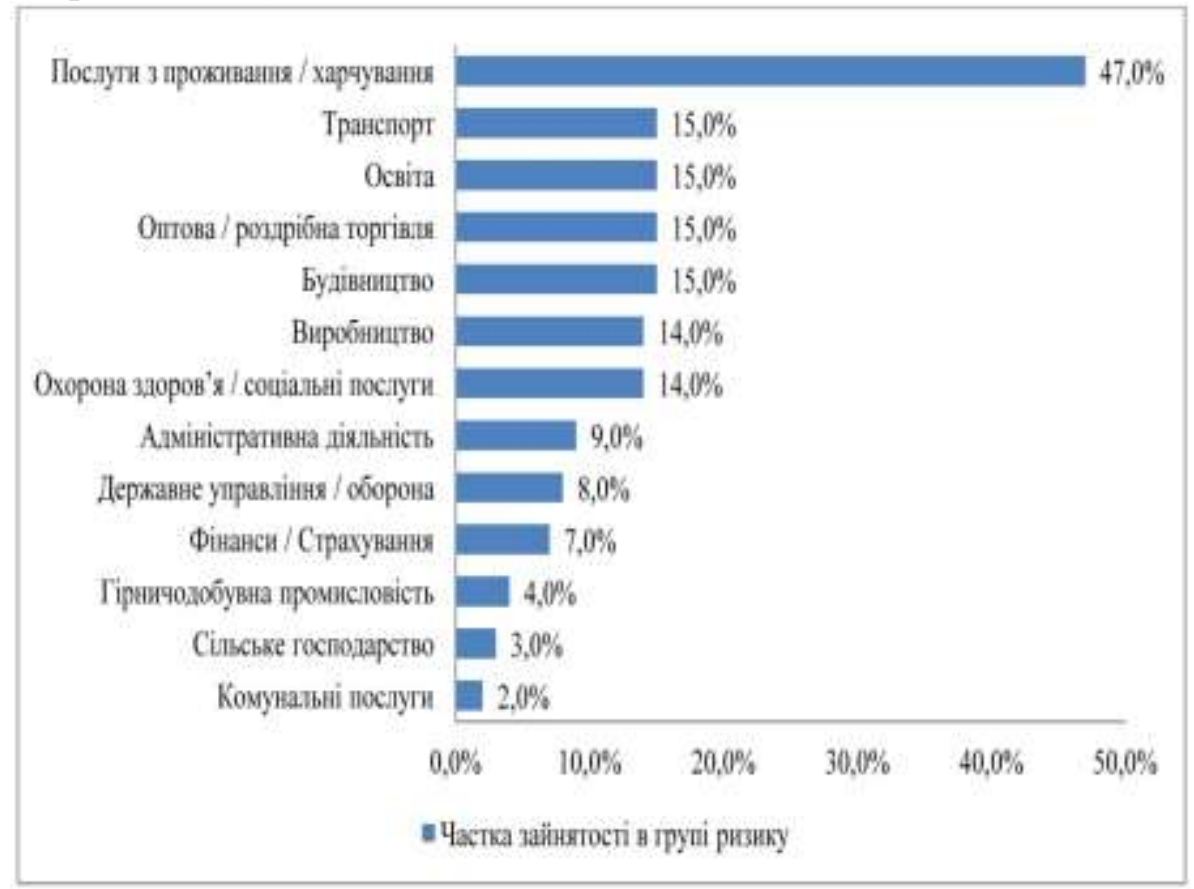

Рисунок 4 - Частка зайнятості в групі ризику безробіття, за секторами

Джерело: побудовано на основі [25].

Але $є$ й група 3 відносно найменш ризикованих напрямів (адміністративна діяльність, державне управління, фінанси, сільське господарство та ін.). Виходячи 3 представлених даних, формування державної політики має виходити з впровадження компенсаторних механізмів щодо найбільш ризикованих сфер діяльності (надання пільгового кредитування, допомога 3 працевлаштування, залучення персоналу до сфер з найменшими ризиками безробіття, перекваліфікація), переорієнтування окремих видів діяльності на споживача цифрових послуг, створення нових робочих місць за рахунок актуальних напрямів діяльності та сучасної цифрової інфраструктури. 


\section{Науковий вісник : Державне управління №1 (7) 2021}

Виходячи із проаналізованого, ключовим питанням наразі постає не факт самих змін показників зайнятості, що породжені процесами автоматизації, появою потреб в нових професіях, а реальною можливістю держави, підприємств, зацікавлених фізичних осіб знаходити баланс між виконанням роботи людьми чи автоматизованими системами та програмами. Нагальним на сьогоднішньому етапі $є$ формування збалансованої державної політики, що зосереджена на процесах перепідготовки фахівців у різних сферах діяльності та працевлаштування на основі сучасних освітніх технологій.

Зміни, що відбуваються на ринку праці з об’єктивних причин призводять до масового безробіття, посилення нерівності, соціальних криз, невідповідності наявних кваліфікованих трудових ресурсів технологічним потребам. Причому, використання інформаційно-комунікативних технологій може як створювати додаткові робочі місця, прискорювати зростання ВВП, покращувати ведення бізнесу, так і дестабілізувати систему влади, встановлювати тотальний контроль, породжувати конфлікти. Зазначені протиріччя вимагають зваженого концептуального підходу до вирішення наявних протиріч, проблематики цифрової трансформації щодо вибудовування секторальної державної політики, спроможної до формування необхідного середовища для розвитку підприємницької діяльності, глобальних змін на ринку праці, створення можливостей у освітній сфері для налаштування на потреби цифрового підприємництва, виробництва, надання послуг та адаптування навчальних програм для підготовки фахівців на міждисциплінарних напрямах.

Міжсекторальне та міждисциплінарне співробітництво відіграє ключову роль при впровадженні конкурентних виробів, що вимагає залучення персоналу 3 гнучкими навичками та здатністю до навчання. Починають виходити на перші ролі саморозвиток та вдосконалення, адаптація до змін, досвід та проєктний менеджмент.

Значною проблемою є неможливість досягти суттєвого рівня показників конкурентоспроможності на основі технологічних 


\section{Науковий вісник : Державне управління №1 (7) 2021}

досягнень та унікальної інноваційної продукції, що дозволяло б прискорити впровадження технологій та вимог «Індустрія 4.0». На цьому шляху державна політика має спрямовуватися на забезпечення можливостей для розвитку технологій, основою чого є поєднання сфери освіти та науки 3 підприємствами, які створюють інноваційну продукцію та формують необхідні навички; забезпечення державної підтримки суб'єктів інноваційної діяльності; збільшення фінансування НДДКР; пільгове кредитування високотехнологічних галузей економіки; створення робочих місць для висококваліфікованих фахівців в інноваційних секторах економіки, пов'язаних 3 цифровими навичками; формування ринку праці та його правове врегулювання на основі вимог, які висувають глобалізаційні та інтеграційні світові процеси; розбудова цифрової інфраструктури; реалізація питань, пов'язаних 3 кібербезпекою; подолання технологічного відставання.

Іншим вектором державної політики у сфері ринку праці в умовах цифрової трансформації $є$ впровадження стимулюючого характеру в оплаті праці в першу чергу в наукоємних та інноваційних сферах діяльності (система оподаткування доходів); посилення соціального захисту фахівців, зосереджених у сфері науки та освіти; законодавче упорядкування питань, пов'язаних 3 виконанням віддаленої роботи, ऑї фіксацією та обліком, дистанційною діяльністю в інших країнах; посилення інституційних меж захисту інтелектуальної власності.

Зазначені напрями реалізації державної політики, обгрунтовані на основі прогнозів розвитку ринку праці та аналізу світових тенденцій, передбачають формування стратегічного документа, який розрахований на довгострокову перспективу та забезпечував би цілеспрямовані дії щодо управління змінами на ринку праці, що породжені цифровою трансформацією. Основою впровадження зазначеного стратегічного документу є залучення інвестиційних ресурсів (як за рахунок державних коштів, так і на основі державно-приватного партнерства [26]),за рахунок яких має розвиватися конкурентне середовище, інноваційна 
діяльність, створюватися актуальні ринкові напрями діяльності та додаткові робочі місця.

Висновки та напрями подальших досліджень. Проведене дослідження державної політики трансформації ринку праці в умовах впливу цифрової епохи виявило, що цифровізація та автоматизація робочих процесів суттєво вплинула на напрями діяльності підприємств, активізацію віддаленої роботи, зростання безробіття та появу нових робочих місць, які потребують цифрових навичок. Спираючись на результати дослідження, державна політика трансформації ринку праці, має відображати ключові напрями: досягнення збалансованості на ринку праці за рахунок створення нових інноваційних робочих місць та постійної перепідготовки фахівців у відповідності до актуальних потреб; розвиток цифрової інфраструктури; впровадження інноваційної діяльності в економічній сфері на основі технологій концепції Індустрія 4.0; підвищення продуктивності праці та посилення конкурентоспроможності за рахунок впровадження цифрових технологій; впровадження системних змін у сферу обслуговування (збільшення частки цифрових послуг, розширені можливості та підвищена якість послуг; поєднання окремих послуг в єдиному цифровому просторі); збільшення кількості працездатного населення, задіяного у процесах цифрової трансформації.

Враховуючи значну мінливість на ринку праці, що прискорилася 3 появою широкого впровадження сучасних інноваційних технологій практично в усі сфери людської діяльності, державне управління стикається 3 необхідністю вироблення адаптивних підходів щодо взаємодії зі сферою цифрової економіки. В основі державної політики, спрямованої на адаптацію ринку праці до змін, спричинених цифровою трансформацією, має стати розроблення та прийняття стратегічного документу 3 визначеними чіткими цілями, напрямами реалізації (освіта, наука, інвестиції, інфраструктура, соціальний захист) та дієвим інструментарієм забезпечення розвитку ринку праці. Враховуючи нерозвиненість інституційного середовища, пов'язаного 3 функціонуванням 


\section{Науковий вісник : Державне управління №1 (7) 2021}

цифрових технологій в Україні, реалізація вказаних напрямів потребує додаткового врегулювання різних аспектів соціальної та економічної діяльності суб'єктів, пов'язаних 3 впровадженням державної політики трансформації ринку праці, що передбачає прийняття окремих законодавчих актів у зазначеній сфері.

Напрямами подальших досліджень необхідно визначити пошук підходів до формування правових та економічних механізмів реалізації державної політики трансформації ринку праці в умовах сучасних викликів.

\section{Список використаних джерел}

1. Костриця В. І., Бурлай Т. В. Неформальна та атипова зайнятість як «нова нормальність» у світі та Україні. Економіка і прогнозування. 2019. № 1. C. 7 - 34 .

2. Туль С. І. Стан і перспективи розвитку діджиталізованого ринку праці в Україні. Бізнес Інформ. 2019. №7. С. 182 - 189.

3. Pauceanu, A. M., Rabie, N., Moustafa, A. Employability in the fourth industrial revolution. Economics and Sociology. 2020. № 13(3), P. 269 283. doi:10.14254/2071- 789X.2020/13-3/17.

4. Hirschi A. The Fourth Industrial Revolution: Issues and Implications for Career Research and Practice. The Career Development Quarterly. 2018. № 66 (3). P. 192 - 204.

5. Brougham D., Haar J. Smart Technology, Artificial Intelligence, Robotics, and Algorithms (STARA): Employees' perceptions of our future workplace. Journal of Management \& Organization. 2017. № 24(2). P. 239 - 257. doi:10.1017/jmo.2016.55.

6. Король С. Я., Польовик С. В. Діджиталізація економіки як фактор професійного розвитку. Modern Economics. 2019. № 18. С. 67 - 73.

7. Rifkin J. The Third Industrial Revolution: How Lateral Power Is Transforming Energy, the Economy, and the World 2011. URL: https://cutt.ly/njSk0xT (дата звернення : 24.12.2020).

8. Хандій О. О., Шамілева Л. Л. Вплив цифрових трансформацій на економіку та сферу праці: соціально-економічні ризики та наслідки. Економічний вісник Донбасу. 2019. № 3 (57). С. 181 - 188.

9. Хуатэн М., Чжаоли. М., Дели Я., Хуалей В. Цифровая трансформация Китая. Опыт преобразования инфраструктуры 


\section{Науковий вісник : Державне управління №1 (7) 2021}

национальной экономики. М.: Интеллектуальная литература, 2019. $250 \mathrm{c}$.

10. Національна стратегія 4.0. Проект для Кабінету Міністрів України. URL: $\quad$ https://industry4-0-ukraine.com.ua/2019/01/02/ukrainskastrategiya-industrii-4-0-7-napriankiv-rozvutku/. (дата звернення: 24.12.2020).

11. Going Digital: Shaping Policies, Improving Lives. OECD Publishing. Paris, 2019. URL : https://dx.doi.org/10.1787/9789264312012-en (дата звернення: 24.12.2020).

12. Vectors of digital transformation. Digital Economy Papers, № 273. OECD, 2019. URL: https://doi.org/10.1787/5ade2bba-en (дата звернення: 24.12.2020).

13. Публічне управління : термінол. слов. / уклад. : В. С. Куйбіда, М. М. Білинська, О. М. Петроє та ін. ; за заг. ред. В. С. Куйбіди, М. М. Білинської, О. М. Петроє. Київ : НАДУ, 2018. 224 с.

14. Readiness for the Future of Production Report 2018. WEF, 2018. 254 p.

15. The Future of Jobs Report 2020. WEF, 2020. 162 p. URL : http://www3.weforum.org/docs/WEF_Future_of_Jobs_2020.pdf (дата звернення: 24.12.2020).

16. Global Employment Trends for Youth 2020: Technology and the future of jobs. International Labour Office - Geneva: ILO, 2020. $184 \mathrm{p}$.

17. UNESCO Institute for Statistics (UIS). UIS Education Statistics. 2019. URL : http:// data.uis.unesco.org (дата звернення: 24.12.2020).

18. Інфляційний звіт. Жовтень 2020 року. URL : https://bank.gov.ua/monetary/report. (дата звернення: 24.12.2020).

19. Jobs of Tomorrow: Mapping Opportunity in the New Economy. WEF, 2020 . 28 $\mathrm{p}$.

URL : http://www3.weforum.org/docs/WEF_Jobs_of_Tomorrow_2020.pdf (дата звернення: 24.12.2020).

20. Autor D., Dorn D. This Job is «Getting Old»: Measuring Changes in Job Opportunities using Occupational Age Structure. American Economic Review: Papers \& Proceedings. 2009. Vol. 99. № 2. P. 45-51.

21. Accenture. It's Learning, Just Not As We Know It: How to Accelerate Skills Acquisition in the Age of Intelligent Technologies, 2018. URL : https://www.accenture.com/us-en/insights/future-

workforce/transforming-learning (дата звернення: 24.12.2020).

22. The Future of Jobs Report 2018. World Economic Forum, 2018. 134 p.

23. Organization for Economic Co-operation and Development (OECD), OECD Data: Harmonised unemployment rate (HUR), January-June 2020, 


\section{Науковий вісник : Державне управління №1 (7) 2021}

2020. URL : https://data.oecd.org/unemp/harmonisedunemployment-ratehur.htm (дата звернення: 24.12.2020).

24. International Labour Organization (ILO), ILO Monitor: COVID-19 and the World of Work, Second Edition, Updated estimates and analysis, 7 April 2020. URL: https://www.ilo.org/wcmsp5/groups/public/--dgreports/---dcomm/documents/briefingnote/wcms_740877.pdf (дата звернення: 24.12.2020).

25. Brussevich M., Dabla-Norris E., Khalid S. Who Will Bear the Brunt of Lockdown Policies? Evidence From Tele-Workability Measures Across Countries (2020). IMF Working Papers № 20/88. IMF, 2020. 24 p.

26. Kruhlov V. V., Tereshchenko D. A. Public-Private Partnership as Tool for Developing Regional Labor Potential. Sci. innov. 2019. №15(6). P. $05-13$.

\section{References}

1. Kostrytsya, V. \& Burlai, T. (2019). Neformal'na ta atypova zajnjatist' jak «nova normal'nist'» u sviti ta Ukrai'ni [Undeclared work as a new normality globally and in Ukraine] Ekonomika i prognozuvannja Economy and Forecasting, 1. (pp. 7-34) [in Ukrainian].

2. Tul S. I. (2019). Stan i perspektyvy rozvytku didzhytalizovanogo rynku praci v Ukrai'ni. [The Status and Prospects for Development of the Digitalized Labor Market in Ukraine]. Biznes Inform - Business Inform, 7. (pp. 182-189) [in Ukrainian].

3. Pauceanu, A. M., Rabie, N. \& Moustafa, A. (2020). Employability in the fourth industrial revolution. Economics and Sociology, 13(3). (pp. 269283). doi:10.14254/2071- 789X.2020/13-3/17 [in English].

4. Hirschi, A. (2018). The Fourth Industrial Revolution: Issues and Implications for Career Research and Practice. The Career Development Quarterly, vol. 66 (3). (pp. 192-204) [in English].

5. Brougham, D. \& Haar, J. (2017). Smart Technology, Artificial Intelligence, Robotics, and Algorithms (STARA): Employees' perceptions of our future workplace. Journal of Management \& Organization, 24(2). (pp. 239-257). doi: 10.1017/jmo.2016.55 [in English].

6. Korol, S. \& Polovyk, Ye. (2019). Didzhytalizacija ekonomiky jak faktor profesijnogo rozvytku. [Digitization of the Economy as Professional Development Factor]. Modern Economics, 18. (pp. 67-73) [in Ukrainian].

7. Rifkin, J. (2011). The Third Industrial Revolution: How Lateral Power Is Transforming Energy, the Economy, and the World - 2011. Retrieved 


\section{Науковий вісник : Державне управління №1 (7) 2021}

from http://www.huffingtonpost.com/jeremy-rifkin/the-third-industrialrevo_b_981168.html [in English].

8. Khandii, O. \& Shamileva, L. (2019). Vplyv cyfrovyh transformacij na ekonomiku ta sferu praci: social'no-ekonomichni ryzyky ta naslidky. [The impact of digital transformation on the economy and labor: socioeconomic risks and implications] Ekonomichnyj visnyk Donbasu Economic Herald of the Donbas, № 3 (57). (pp. 181-188) [in Ukrainian].

9. Huateng, M., Zhaoli, M., Delhi, Y. \& Hualii, W. (2019). Tsifrovaya transformatsiya Kitaya. Opyit preobrazovaniya infrastrukturyi natsionalnoy ekonomiki. [China's digital transformation. Experience in transforming the infrastructure of the national economy]. Moscow: Intellectual literature [in Russian].

10. Natsional'na stratehiya 4.0. Proekt dlya Kabinetu Ministriv Ukrayiny. [National Strategy 4.0. Project for the Cabinet of Ministers of Ukraine]. Retrieved from https://industry4-0-ukraine.com.ua/2019/01/02/ukrainskastrategiya-industrii-4-0-7-napriankiv-rozvutku/ [in Ukrainian].

11. Going Digital: Shaping Policies, Improving Lives. (2019). OECD Publishing. Paris. doi: 10.1787/9789264312012-en [in English].

12. Vectors of digital transformation. (2019). Digital Economy Papers, № 273. OECD. doi:10.1787/5ade2bba-en [in English].

13. Kuibida, V. S., Bilynska, M. M. \& Petroie, O. M. (Ed.). (2018). Publichne upravlinnia: terminolohichnyi slovnyk / uklad. : V. S. Kujbida, M. M. Bilyns'ka, O. M. Petroje ta in. ; za zag. red. V. S. Kujbidy, M. M. Bilyns'koi', O. M. Petroje [Public administration: a Terminology Dictionary / comp. : V. S. Kuybida, M. M. Bilynska, O. M. Petroe and others]. Kyiv: NAPA [in Ukrainian].

14. Readiness for the Future of Production Report 2018. (2018). [in English].

15. The Future of Jobs Report 2020. (2020). WEF. Retrieved from http://www3.weforum.org/docs/WEF_Future_of_Jobs_2020.pdf [in English].

16. Global Employment Trends for Youth 2020: Technology and the future of jobs International Labour Office. (2020). Geneva: ILO [in English].

17. UNESCO Institute for Statistics (UIS). 2019. UIS Education Statistics. Retrieved from http:// data.uis.unesco.org [in English].

18. Inflyatsiynyy zvit. Zhovten' 2020 roku [Inflation Report. October 2020]. Retrieved from https://bank.gov.ua/monetary/report [in Ukrainian].

19. Jobs of Tomorrow: Mapping Opportunity in the New Economy. (2020). WEF.

$28 \mathrm{p}$ Retrieved from

http://www3.weforum.org/docs/WEF_Jobs_of_Tomorrow_2020.pdf [in English]. 
20. Autor, D. \& Dorn, D. (2009). This Job is «Getting Old»: Measuring Changes in Job Opportunities using Occupational Age Structure. American Economic Review: Papers \& Proceedings, 2(99). (pp. 45-51) [in English].

21. Accenture (2018). It's Learning, Just Not As We Know It: How to Accelerate Skills Acquisition in the Age of Intelligent Technologies [in English].

22. The Future of Jobs Report 2018. (2018). World Economic Forum [in English].

23. Organization for Economic Co-operation and Development (OECD), OECD Data: Harmonised unemployment rate (HUR), January-June 2020, (2020). Retrieved from

https://data.oecd.org/unemp/harmonisedunemployment-rate-hur.htm [in English].

24. International Labour Organization (ILO), ILO Monitor: COVID-19 and the World of Work, Second Edition, Updated estimates and analysis, 7 April 2020. Retrieved from : https://www.ilo.org/wcmsp5/groups/public/--dgreports/---dcomm/documents/briefingnote/wcms_740877.pdf [in English].

25. Brussevich, M., Dabla-Norris, E. \& Khalid, S. (2020). Who Will Bear the Brunt of Lockdown Policies? Evidence From Tele-Workability Measures Across Countries. IMF Working Papers № 20/88. IMF. [in English].

26. Kruhlov, V. V. \& Tereshchenko, D. A. (2019). Public-Private Partnership as Tool for Developing Regional Labor Potential. Sci. innov., 15(6). (pp. 05-13) [in English]. 


\title{
PUBLIC POLICY OF LABOR MARKET TRANSFORMATION: CHALLENGES OF THE DIGITAL AGE
}

\section{Kruhlov Vitalii}

\begin{abstract}
The processes of technological change, which affected the livelihood of the state and production, are reflected in the vast majority of human activityis a consequence of the rapid development of the digital economy. The new directions of activity of enterprises, institutions and organizations, born of innovative technologies, require staff to have the appropriate professional skills related to knowledge of the digital economy. The purpose of the study is to analyze the current state of the state policy of transforming the labor market and the formation of approaches to the implementation of changes, taking into account the challenges of the digital era. As the labor market development process shows, digitalization and technological progress have significantly influenced economic activity, revealing the requirements for the adaptive skills of specialists. This, in turn, will lead to the significant reduction and elimination of jobs in the near future. Digital transformation is a complex change due to the increased impact of technology aimed at relations in the social and economic spheres. The concept of Industry 4.0 provides for the emergence and further development of modern innovative activities. There is the urgent need to obtain and adapt the working population to the changing demands of the labor market. The introduction of new areas will require the significant number of employees, at the same time - the disappearance of obsolete areas will lead to significant unemployment. It is determined that the state policy related to the transformation of the labor market is faced with issues aimed at: regulating the balance between the performance of human work and automated systems; control over the safe use of leading technologies; formation of the necessary environment for business competition; increase in R\&D funding; digital infrastructure development; introduction of stimulating character in payment of work in science-intensive and innovative spheres of activity; legislative regulation of issues related to the performance of remote work; strengthening the institutional boundaries of intellectual property protection; state support of subjects of innovative activity; attracting significant investments in the development of science and education; retraining of specialists in various fields of activity and employment.
\end{abstract}

Key words: public policy, labor market, digital transformation, information and communication technologies 